Article

\title{
Anti-Inflammatory Effects of (9Z,11E)-13-Oxooctadeca-9,11-dienoic Acid (13-KODE) Derived from Salicornia herbacea L. on Lipopolysaccharide-Stimulated Murine Macrophage via NF-kB and MAPK Inhibition and Nrf2/HO-1 Signaling Activation
}

\author{
Yu-Chan Ko ${ }^{1,+}$, Hack Sun Choi ${ }^{1,2,3,4,+}$, Su-Lim Kim ${ }^{1,2,3,4}$, Bong-Sik Yun ${ }^{5}$ and Dong-Sun Lee ${ }^{1,2,3,4,6, *(\mathbb{D})}$ \\ check for \\ updates \\ 1 Interdisciplinary Graduate Program in Advanced Convergence Technology \& Science, \\ Jeju National University, Jeju 63243, Korea; uchan@jejunu.ac.kr (Y.-C.K.); choix074@jejunu.ac.kr (H.S.C.); \\ ks11101@jejunu.ac.kr (S.-L.K.) \\ 2 Subtropical/Tropical Organism Gene Bank, Jeju National University, Jeju 63243, Korea \\ 3 Bio-Health Materials Core-Facility Center, Jeju National University, Jeju 63243, Korea \\ 4 Practical Translational Research Center, Jeju National University, Jeju 63243, Korea \\ 5 Faculty of Division of Biotechnology, College of Environmental and Bioresource Sciences, \\ Jeonbuk National University, Iksan 54596, Korea; bsyun@jbnu.ac.kr \\ 6 Faculty of Biotechnology, College of Applied Life Sciences, Jeju National University, Jeju 63243, Korea \\ * Correspondence: dongsunlee@jejunu.ac.kr; Tel.: +82-64-754-3340; Fax: +82-64-751-3780 \\ + First two authors share equal contribution.
}

Citation: Ko, Y.-C.; Choi, H.S.; Kim, S.-L.; Yun, B.-S.; Lee, D.-S. Anti-Inflammatory Effects of (9Z,11E)-13-Oxooctadeca-9,11dienoic Acid (13-KODE) Derived from Salicornia herbacea L. on Lipopolysaccharide-Stimulated Murine Macrophage via NF-kB and MAPK Inhibition and Nrf2/HO-1 Signaling Activation. Antioxidants 2022, 11, 180. https://doi.org/ 10.3390/antiox11020180

Academic Editors: Jose M. Prieto, Guillermo R. Schinella and Stanley Omaye

Received: 22 December 2021

Accepted: 18 January 2022

Published: 18 January 2022

Publisher's Note: MDPI stays neutral with regard to jurisdictional claims in published maps and institutional affiliations.

Copyright: (C) 2022 by the authors. Licensee MDPI, Basel, Switzerland. This article is an open access article distributed under the terms and conditions of the Creative Commons Attribution (CC BY) license (https:// creativecommons.org/licenses/by/ $4.0 /)$.

\begin{abstract}
Glasswort (Salicornia herbacea L.) is a halophyte that exhibits antioxidant and antidiabetic effects. Only a few studies have been conducted on its antioxidant effects. Here, we isolated an antioxidant using an activity-based purification method, and the resulting compound was identified as (9Z,11E)-13-Oxooctadeca-9,11-dienoic acid (13-KODE). We investigated its ability to suppress inflammatory responses and the molecular mechanisms underlying these abilities using lipopolysaccharide-stimulated RAW 264.7 macrophage cells. We studied the anti-inflammatory effects of 13-KODE derived from $S$. herbacea L on RAW 264.7 macrophages. 13-KODE inhibited lipopolysaccharide (LPS)-induced nitric oxide (NO) production by suppressing inducible NO synthase and suppressed LPS-induced tumor necrosis factor and interleukin- $1 \beta$ expression in RAW 264.7 macrophages. LPS-mediated nuclear localization of NF- $\mathrm{KB}$ and mitogen-activated protein kinase activation were inhibited by 13-KODE. 13-KODE significantly reduced LPS-induced production of reactive oxygen species and increased the expression of nuclear factor erythroid-2 like 2 (Nfe2I2) and heme oxygenase 1. Overall, our results indicate that 13-KODE may have potential for treating inflammation.
\end{abstract}

Keywords: (9Z,11E)-13-Oxooctadeca-9,11-dienoic acid (13-KODE); Salicornia herbacea L.; inflammation; Nrf-2 (Nfe2I2); macrophage; antioxidant

\section{Introduction}

Inflammation is the complex biological response of body tissues against pathogens and damaged cells [1]. It is a protective response involving immune cells and molecular mediators. The function of inflammation is to eliminate necrotic cells and damaged tissues. Acute inflammation is considered a part of innate immunity and represents the first line of defense against foreign bacteria and dangerous molecules [2]. Infectious agents and cell damage activate inflammatory cells and induce inflammatory signaling pathways, such as NF- $\mathrm{B}$, mitogen-activated protein kinase (MAPK), and JAKSTAT signaling pathways [3]. Lipopolysaccharide (LPS), an endotoxin derived from the outer membrane of Escherichia coli, induces inflammation and is used to develop disease models to examine the anti-inflammatory effects of drugs and natural compounds [4,5]. 
Macrophages exposed to LPS produce proinflammatory mediators, cytokines, and reactive oxygen species (ROS) [6,7]. The major proinflammatory mediators consist of nitric oxide (NO) and prostaglandin E2, which are produced by inducible NO synthase (iNOS) and cyclooxygenase-2, respectively $[8,9]$. LPS-treated macrophages induce tumor necrosis factor (TNF)- $\alpha$ and interleukin (IL)-1 $\beta$, and these molecules contribute to various inflammatory diseases $[10,11]$. Furthermore, LPS-stimulated macrophages secrete proinflammatory cytokines and growth factors [12]. LPS exposure results in the production of proinflammatory mediators and proinflammatory cytokines through NF- $\mathrm{kB}$ activation $[13,14]$. Inflammationrelated gene expression of immune cells is regulated by the NF-kB pathway [13,15]. LPS stimulation promotes the nuclear translocation of NF- $\kappa$ B p65 through I $k \mathrm{~B}-\alpha$ reduction. MAPKs regulate cell proliferation, cycle arrest, migration, differentiation, senescence and apoptosis [16]. Inflammation induces ROS production and decreases the production of antioxidant enzymes $[17,18]$. The crosstalk between inflammation and oxidative stress is important in diseases. The evidence of this crosstalk and the protective effects of natural compounds against oxidative stress and inflammatory response has been shown in previous studies [19-25]. Heme oxygenase-1 (HO-1) is regulated by nuclear factor erythroid-2 like 2 (Nfe2I2) and cleaves heme to form biliverdin, which is subsequently converted into bilirubin by biliverdin reductase. HO-1 is associated with antioxidant, anti-inflammatory, and cytoprotective functions and has emerged as a target molecule with therapeutic implications [26]. Nfe2I2 plays a central role against inflammation and oxidative damage $[17,27,28]$.

Glasswort (Salicornia herbacea L.) is a halophytic plant that inhabits the mudflats of Korea and has been used as a seasoning and in folk medicine for intestinal ailments, nephropathy, and hepatitis [29]. The extract of glasswort prevents high fat diet-induced hyperglycemia and hyperlipidemia in mice and induces antioxidant and skin-whitening effects $[30,31]$. Methyl 3,5-dicaffeoyl quinate (MDQ), an active compound present in S. herbacea. L produces anti-melanogenic effects through p-p38 and p-ERK1/2 signaling in B16F10 mouse melanoma cells [32]. (9Z,11E)-13-Oxooctadeca-9,11-dienoic acid [13-KODE (13-oxo-ode)] is a compound present in tomato fruit; it has health benefits and acts as a peroxisome proliferator-activated receptor- $\alpha(\operatorname{PPAR} \alpha)$ agonist [33]. Furthermore, linoleic acid (LA) is oxidized into 13-hydroperoxy-9Z, 11E-octadecadienoic acid (13-HpODE) by lipoxygenase, and 13-HpODE is reduced to 13-hydroyoctadecadienoic acid (13-HODE) by glutathione peroxidase. 13-KODE (13-oxo-ode) is derived from 13-HODE by hydroxy fatty acid dehydrogenase [34]. However, the anti-inflammatory effects of 13-KODE derived from $S$. herbacea $\mathrm{L}$. in murine macrophages have not been studied yet.

Here, we examined the anti-inflammatory activity of 13-KODE derived from S. herbacea L. using murine macrophages. We isolated the antioxidant component using an antioxidant assay-based purification protocol and the isolated compound, (9Z,11E)-13-Oxooctadeca9,11-dienoic acid (13-KODE) was found to exhibit anti-inflammatory activity. We showed that 13-KODE functions as an anti-inflammatory agent by modulating NF- $\mathrm{kB}, \mathrm{ROS}$, and Nfe2I2 signaling in murine macrophages

\section{Materials and Methods}

\subsection{Materials}

Silica gel 60A and gel filtration resin (Sephadex LH-20) were obtained from MilliporeSigma (Burlington, MA, USA). Reversed-phase high-performance liquid chromatography (HPLC)-UV analysis of antioxidants was carried out on a Shimadzu 20A series HPLC system (Kyoto, Japan) (Core-facility center, Jeju, Korea). LPS from E. coli was obtained from InvivoGen (San Diego, CA, USA). Cell proliferation was done using the EZ-cytox Cell Viability Assay Kit (Wellbio, Seoul, Korea). We used 13-KODE purified from S. herbacea L. extracts. All other chemicals were obtained from Millipore-Sigma (Burlington, MA, USA). 


\subsection{Plant Source}

S. herbacea L. was purchased from Dasarang, Ltd. (Sinan, Korea). The plants were ground and lyophilized. A lyophilized sample (no. 2020_10) was deposited at the Department of Biomaterials, Jeju National University (Core-facility center, Jeju, Korea).

\subsection{Purification of (9Z,11E)-13-Oxooctadeca-9,11-dienoic Acid (13-KODE)}

The ground sample of $S$. herbacea L. (1000 g) was incubated with absolute methanol at $28{ }^{\circ} \mathrm{C}$ for $16 \mathrm{~h}$. The antioxidant-based isolation is described in Figure 1A. We mixed methanol-extracted samples with distilled water and then evaporated the $100 \%$ methanol off using a rotary evaporator (Heidolph, Schwabach, Germany). The water-soluble portion was extracted with 1X ethyl acetate (EA). We isolated and then evaporated the EA fraction. The evaporated purified samples were dissolved in 100\% methanol. The EA extracts were applied onto a silica gel resin (column size; $30 \mathrm{~mm} \times 300 \mathrm{~mm}$ ) and isolated with chloroform:methanol (30:1) (Figure S1). The extracts were divided into several fractions, evaporated, dissolved in methanol, and tested for antioxidant activity. The \#6 fraction showed an antioxidant effect; it was applied to a Sephadex LH-20 gel (column size; $30 \mathrm{~mm} \times 300 \mathrm{~mm}$ ) and separated into four parts (Figure S2). Each part was evaluated for antioxidant activity and part \#2 exhibited an effect. Part \#2 was then loaded onto a preparatory thin-layer chromatography (TLC) plate (glass plate; $200 \mathrm{~mm} \times 200 \mathrm{~mm}$ ). The separated bands were examined for antioxidant activity (Figure S3). Fraction \#1 was injected onto an HPLC column (Shimadzu LC-20A, Kyoto, Japan) (Shim-pack GIS C-18 column and elution rate; $2 \mathrm{~mL} / \mathrm{min}$ ) and a gradient elution was employed as follows: 0-60\% acetonitrile for $20 \mathrm{~min}, 60-100 \%$ acetonitrile $10 \mathrm{~min}$, and $100 \%$ acetonitrile for $20 \mathrm{~min}$. The injection volume was $500 \mu \mathrm{l}$ (Figure S4). The purified peak was observed at $32.8 \mathrm{~min}$ (Figure 1B).

A

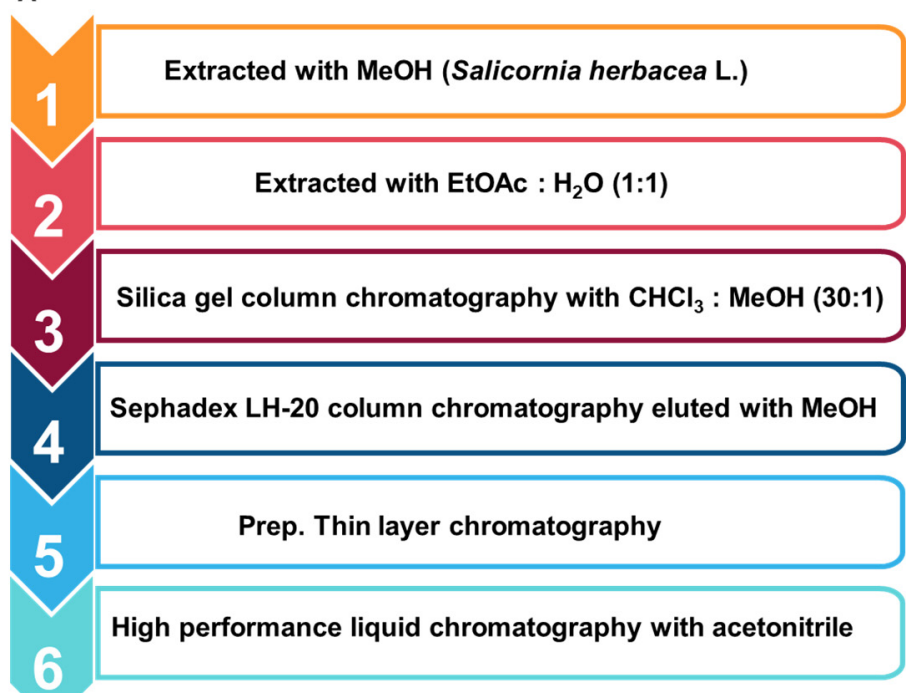

B
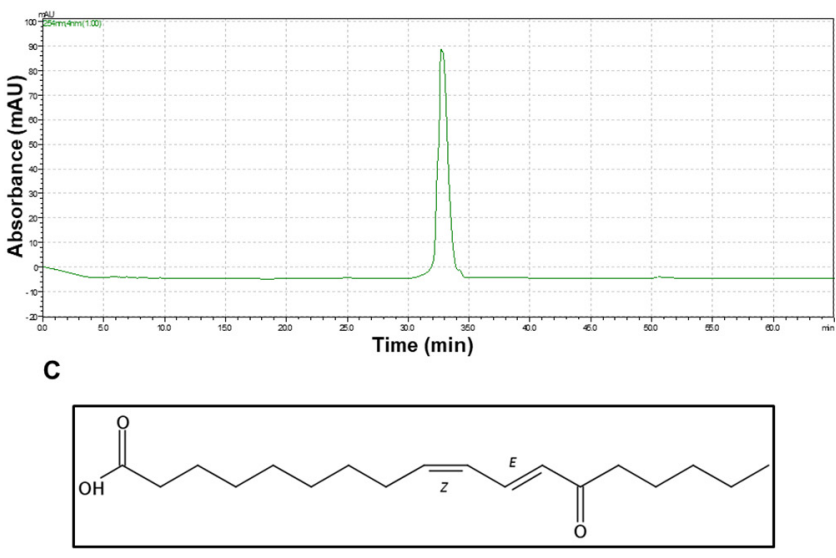

13-KODE (= 13-Oxo-9Z,11E-octadecadienoic acid, (9Z,11E)-13-Oxooctadeca-9,11-dienoic acid)

Molecular formula: $\mathrm{C}_{18} \mathrm{H}_{30} \mathrm{O}_{3}$
Molecular weight: $294(\mathrm{~m} / \mathrm{z} 293[\mathrm{M}-\mathrm{H}]-, 295[\mathrm{M}+\mathrm{H}]+)$

Figure 1. Procedure for the isolation of an antioxidant from S. herbacea L. and the molecular structure of 13-KODE. (A) Purification flowchart of the antioxidant from S. herbacea L. (B) HPLC analysis of an antioxidant derived from $S$. herbacea L. (C) Chemical structure of 13-KODE, the antioxidant purified from S. herbacea L.

\subsection{Structural Analysis of the Isolated Sample}

The chemical structure of the isolated compound was determined by mass spectrometry and NMR. The molecular weight was established as 294 by ESI-mass spectrometry, which showed quasi-molecular ion peaks at $m / z 295.4[\mathrm{M}+\mathrm{H}]+$ in positive mode and $\mathrm{m} / \mathrm{z}$ 293.4 [M-H]- in negative mode (see Figure S5). The 1H NMR spectrum in $\mathrm{CDCl} 3$ exhibited 
signals resulting from 4 olefinic methines at $\delta 7.48,6.17,6.11$, and 5.88, 11 methylenes at $\delta 2.53,2.34,2.29,1.62,1.62,1.41$, and $1.25-1.35$, and 1 methyl at $\delta 0.88$. In the 13C NMR spectrum, 18 carbon peaks were observed, including 2 carbonyl carbons at $\delta 201.4$ and $178.3,4$ olefinic methine carbons at $\delta 142.6,137.0,129.2$, and 127.0, 11 methylene carbons at $\delta 41.3,33.8,31.5,28.7-29.1,28.2,24.6,24.1$, and 22.5, and 1 methyl carbon at $\delta 13.9$ (see Figure S6). All proton-bearing carbons were assigned by the Heteronuclear Multiple Quantum Coherence (HMQC) spectrum, and the 1H-1H Correlated Spectroscopy (COSY) spectrum revealed four partial structures, $\mathrm{CH} 3-\mathrm{CH} 2-,-\mathrm{CH} 2-\mathrm{CH} 2-,-\mathrm{CH}=\mathrm{CH}-\mathrm{CH}=\mathrm{CH}-\mathrm{CH} 2-$ $\mathrm{CH} 2-$, and -CH2-CH2-CH2- (see Figures $\mathrm{S} 7$ and S8). Further structural elucidation was performed using the Heteronuclear Multiple Bond Correlation (HMBC) spectrum, which showed long-range correlations from the methyl protons at $\delta 0.88$ to the carbons at $\delta 31.5$ and 22.5, from the methylene protons at $\delta 2.53$ to the carbons at $\delta 31.5$ and 24.1, and from the protons at $\delta 6.17$ and 2.53 to the ketone carbonyl carbon at $\delta 201.4$. The methylene protons at $\delta 2.34$ and 1.62 showed a long-range correlation to the carbon at $\delta 178.3$ (see Figures S9 and S10). Finally, the structure of the isolated compound was determined as (9Z,11E)-13-Oxooctadeca-9,11-dienoic acid (13-KODE) by the process of elimination. The geometries of C-9 and C-11 were established as cis and trans, respectively, by the proton coupling constants of 11.0 and $15.5 \mathrm{~Hz}$.

\subsection{Antioxidant Assay}

The antioxidant assay was done by the 2,2-Diphenyl-1-picrylhydrazyl (DPPH) method [35] Several concentrations of $13-\operatorname{KODE}(0,25,50,75$, and $100 \mu \mathrm{M})$ and a representative antioxidant, $10 \mathrm{mM}$ N-acetyl-cysteine (NAC) as a positive control, were incubated with $200 \mu \mathrm{M}$ DPPH solution in a 96-well plate for $20 \mathrm{~min}$. The absorbance at $\mathrm{OD}_{517}$ was examined using a VersaMax plate reader (Molecular Devices, San Jose, CA, USA). The DPPH scavenging activities were determined by the following equation: DPPH scavenging activity $(\%)=\{1-[($ Sample-Blank $) /$ Control $]\} \times 100$.

\subsection{Cell Line and Culture Conditions}

RAW 264.7 macrophages were purchased from the American Type Culture Collection (Manassas, VA, USA). The macrophage cells were cultured in RPMI-1640 medium with 10\% Cytiva HyClone fetal bovine serum (Marlborough, MA, USA) and 1\% Penicillin/Streptomycin (Cytiva, HyClone) at $37{ }^{\circ} \mathrm{C}$ in $5 \% \mathrm{CO}_{2}$.

\subsection{Cell Proliferation Assay}

RAW 264.7 cells $\left(2.5 \times 10^{6}\right.$ cells / plate $)$ were seeded into a 96-well plate for $24 \mathrm{~h}$. The murine macrophages were incubated with increasing concentrations of $13-\mathrm{KODE}(0,25$, $50,100,200,300$, and $400 \mu \mathrm{M}$ ) for one day. Cell proliferation was determined using the EZ-Cytox Cell Viability Assay Kit (Wellbio, Seoul, Korea) following the manufacturer's instructions. The cultured media and reagent solution were mixed at a 10:1 ratio and $100 \mu \mathrm{L}$ of the mixture was added to each well and incubated at $37^{\circ} \mathrm{C}$ for $2 \mathrm{~h}$. The absorbance at $\mathrm{OD}_{492}$ was measured using a VersaMax plate reader (Molecular Devices).

\subsection{NO Assay}

RAW 264.7 macrophages $\left(2.5 \times 10^{6}\right.$ cells/plate $)$ were incubated in a 12-well plate for $24 \mathrm{~h}$. The macrophages were incubated with two concentrations of 13-KODE ( 0 or $100 \mu \mathrm{M})$ without LPS or with several concentrations of $13-\operatorname{KODE}(0,25,50,75$, and $100 \mu \mathrm{M})$ with $1 \mu \mathrm{g} / \mathrm{mL}$ LPS for 1 day. Secretory NO concentrations were measured using the NO Plus Detection kit (LiliF, Gyeonggi, Korea). Then, $100 \mu \mathrm{L}$ of the media and nitrite standard were incubated by adding $50 \mu \mathrm{L}$ of $\mathrm{N} 1$ buffer to each reaction for $30 \mathrm{~min}$, and the combined solution was incubated with $50 \mu \mathrm{L}$ of $\mathrm{N} 2$ buffer for $15 \mathrm{~min}$. The production of NO was determined by measuring the absorbance $\mathrm{OD}_{560}$ using a VersaMax microplate reader (Molecular Devices). 


\subsection{Quantitative Real Time Reverse Transcription Polymerase Chain Reaction (qRT-PCR)}

RAW 264.7 macrophage cells were seeded into a 6-well plate for $24 \mathrm{~h}$. The cells were treated with 13-KODE (50 and $100 \mu \mathrm{M})$ for $1 \mathrm{~h}$ and incubated with LPS $(1 \mu \mathrm{g} / \mathrm{mL})$ for $24 \mathrm{~h}$. Total RNA was extracted using the RNAiso Plus Extraction Kit (TaKaRa, Tokyo, Japan) following manufacturer's instructions. Real time qRT-PCR was carried out using a One Step PrimeScript RT-PCR kit (TaKaRa, Tokyo, Japan). The qRT-PCR reaction mixture contained $10 \mu \mathrm{L}$ of $2 X$ One Step RT-PCR buffer, $0.5 \mu \mathrm{L}$ of PrimeScript RT enzyme Mix, $0.5 \mu \mathrm{L}$ of Takara ExTaq, $1 \mu \mathrm{L}$ of total RNA $(150 \mathrm{ng} / \mu \mathrm{L}), 1 \mu \mathrm{L}$ of forward primer $(10 \mathrm{ng} / \mu \mathrm{L})$, $1 \mu \mathrm{L}$ of reverse primer $(10 \mathrm{ng} / \mu \mathrm{L})$, and $6 \mu \mathrm{L}$ of RNase-free sterile water. We used the comparative $C_{t}$ method for analyzing the relative transcript levels of the target genes. The specific qRT-PCR primers were obtained from Bioneer (Daejeon, Korea) and described in Table S1. The $\beta$-actin gene was used as an internal control.

\subsection{Enzyme-Linked Immunosorbent Assay (ELISA) for Cytokines}

RAW 264.7 macrophage cells were seeded in a 12-well plate. The cells were pretreated with 13-KODE (50 and $100 \mu \mathrm{M})$ for $1 \mathrm{~h}$ and stimulated with LPS $(1 \mu \mathrm{g} / \mathrm{mL})$ for $24 \mathrm{~h}$. The amount of TNF- $\alpha$ and IL- $1 \beta$ in the supernatant medium was measured using a specific ELISA kit. The amount of IL- $1 \beta$ and TNF- $\alpha$ was measured using the IL- $1 \beta$ Mouse and TNF- $\alpha$ ELISA Kit (R\&D, Minneapolis, MN, USA).

\subsection{Western Blot Analysis}

RAW 264.7 macrophage cells were treated with 13-KODE for $1 \mathrm{~h}$ and incubated with $1 \mu \mathrm{g} / \mathrm{mL}$ LPS for $30 \mathrm{~min}$. The cells were lysed using a radioimmunoprecipitation assay (RIPA) buffer (Sigma-Aldrich, Burlington, MA, USA) supplemented with protease inhibitor, $10 \mathrm{mM}$ sodium fluoride, and $10 \mathrm{mM}$ sodium vanadate. Each lysate was separated using sodium dodecyl sulfate polyacrylamide gel electrophoresis (SDS-PAGE), and the proteins were transferred to polyvinylidene fluoride (PVDF) membranes (Sigma-Aldrich, Burlington, MA, USA). After incubating with Odyssey ${ }^{\circledR}$ Blocking Buffer (PBS) (LI-COR, Lincoln, NE, USA) at room temperature for $1 \mathrm{~h}$, the membranes were incubated for $3 \mathrm{~h}$ at room temperature with primary antibodies. After washing three times with 1X PBS containing $0.1 \%$ Tween 20 , the membrane was incubated with IRDye ${ }^{\circledR} 680 \mathrm{RD}$ - and IRDye ${ }^{\circledR}$ 800CW-labeled antibody in Odyssey blocking buffer (1X PBS) supplemented with 1X PBS containing $0.1 \%$ Tween 20 at room temperature for $1 \mathrm{~h}$. The protein bands were visualized using Odyssey CLx (LI-COR, Lincoln, NE, USA). Anti-pp38, anti-JNK, anti-pJNK, antiERK1/2, anti-pERK1/2, anti-p65, anti-NRF2 (Nfe212), and anti-HO-1 antibodies were obtained from Cell Signaling Technology (Beverly, MA, USA). Anti-p38, anti- $\beta$-actin, and anti-Lamin B antibodies were obtained from Santa Cruz Biotechnology (Dallas, TX, USA).

\subsection{Immunofluorescence Staining}

RAW 264.7 macrophage cells $\left(5 \times 10^{5}\right.$ cells $\left./ \mathrm{mL}\right)$ were incubated in a 96-well black plate with a glass bottom (Eppendorf, Hamburg, Germany). The cells were pretreated with 13-KODE for $1 \mathrm{~h}$ and stimulated with LPS $(1 \mu \mathrm{g} / \mathrm{mL})$ for $60 \mathrm{~min}$. The cells were fixed in $4 \%$ paraformaldehyde for $15 \mathrm{~min}$, permeabilized with $0.1 \%$ Triton X-100 for $5 \mathrm{~min}$, and treated with $50 \mathrm{mM} \mathrm{NH}_{4} \mathrm{Cl}$ for $5 \mathrm{~min}$. The cells were blocked with PBS containing 3\% BSA for $30 \mathrm{~min}$ and stained with p65 antibody (Cell Signaling Technology) overnight at $4{ }^{\circ} \mathrm{C}$. The stained cells were washed with 1 X PBS and incubated with goat anti-mouse IgG Alexa 488-conjugated secondary antibodies. The cells were subsequently stained using mounting medium with DAPI (Abcam, Cambridge, UK) and detected with an automated microscope (Lionheart, Biotek, VT, USA).

\subsection{Determination of Cellular ROS by Invitrogen ${ }^{\circledR}$ CellROX $^{\circledR}$ Green Reagent}

The cellular ROS concentration was determined using Invitrogen CellROX ${ }^{\circledR}$ Green Reagent (Invitrogen, Carlsbad, CA, USA) following the manufacturer's instructions. RAW 264.7 macrophage cells $\left(1 \times 10^{6}\right.$ cells / plate $)$ were seeded in a 96-well plate for $24 \mathrm{~h}$. The 
cells were pretreated with 13-KODE or N-acetyl-L-cysteine (NAC) for 60 min and incubated with LPS $(1 \mu \mathrm{g} / \mathrm{mL})$ for $30 \mathrm{~min}$. Then, the cells were stained with CellROX green dye for $10 \mathrm{~min}$ at $37^{\circ} \mathrm{C}$. After washing with $1 \mathrm{X}$ PBS, the stained ROS were captured using an automated microscope (Lionheart, Biotek, VT, USA).

\subsection{Statistical Analysis}

The data was the result of three independent experiments and reported as the mean \pm standard deviation. All data were analyzed using one-way analysis of variance and evaluated using GraphPad Prism 8.0 (GraphPad Software Inc., San Diego, CA, USA), and ${ }^{* *} p<0.01,{ }^{* *} p<0.001$ was considered a significant statistical difference.

\section{Results}

\subsection{Purification of an Antioxidant Derived from S. herbacea $L$.}

The antioxidant-guided (DPPH assay) purification steps are presented in Figure 1A. The ground powder of S. herbacea L. was extracted with $100 \%$ methanol, and the dried samples of $S$. herbacea L. were extracted with EA and $\mathrm{H}_{2} \mathrm{O}(v / v=1: 1)$. The EA extracts were isolated using silica gel chromatography, Sephadex LH-20 gel chromatography, preparatory thin layer chromatography (prep-TLC), and HPLC (Figures 1A and S1-S4). The isolated sample was shown using HPLC and it has antioxidant activity (Figure 1B).

\subsection{Structure of Isolated Antioxidant and the Effect of 13-KODE on Cell Proliferation}

The purified antioxidant was identified as 13-Oxo-9Z, 11E-octadecadienoic acid (13KODE) using NMR spectrometry (Figures 1C and S5-S10). Cell proliferation was assessed using 13-KODE in murine RAW 264.7 macrophages. The cells were incubated with 13KODE up to $400 \mu \mathrm{M}$. The results indicated that 13-KODE $(100 \mu \mathrm{M})$ without LPS, LPS (up to $10 \mu \mathrm{g}$ ) without 13-KODE, and the combination of LPS and 13-KODE exhibited no growth inhibition on macrophage cells (Figure 2A,B), whereas $200 \mu \mathrm{M}$ 13-KODE inhibited cell proliferation by $42 \%$.

\subsection{Effect of 13-KODE on LPS-Stimulated Production of Proinflammatory Mediators in RAW 264.7 Cells}

To determine the suppressive effect of 13-KODE on LPS-stimulated NO secretion, we tested murine macrophage cells with $13-\operatorname{KODE}(25,50,75$, and $100 \mu \mathrm{M})$ for 1 day with or without LPS. It was observed that 13-KODE $(100 \mu \mathrm{M})$ without LPS did not change NO secretion of macrophages (Figure 2D). Additionally, we found that LPS-induced NO secretion and 13-KODE decreased LPS-stimulated NO secretion. LPS stimulation increased NO secretion up to 42-fold, whereas 13-KODE treatment resulted in a $21 \%, 49 \%, 70 \%$, and $90 \%$ reduction, respectively, compared with LPS-stimulated cells (Figure 2D). We examined the expression of iNOS using an immunoblot assay. The LPS-treated RAW 264.7 macrophages increased the expression of iNOS, whereas 13-KODE markedly reduced LPS-induced iNOS protein levels. The mRNA level of iNOS was measured in LPS-treated RAW 264.7 macrophages. LPS-induced mRNA levels of the iNOS gene, whereas 13-KODE treatment resulted in a decrease in iNOS mRNA (Figure 2E). Thus, 13-KODE decreased NO secretion by decreasing iNOS gene expression. 


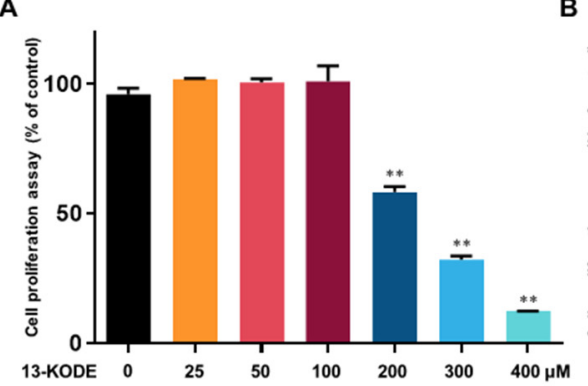

D

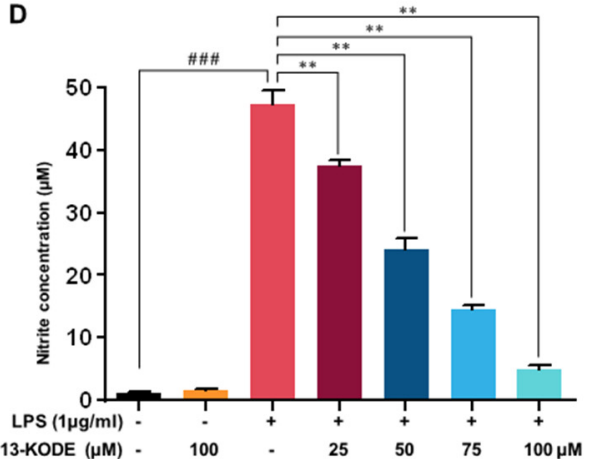

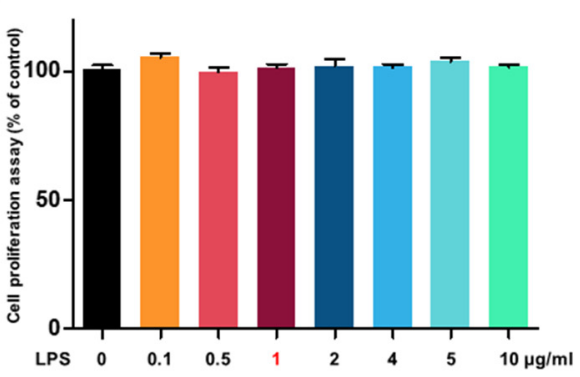

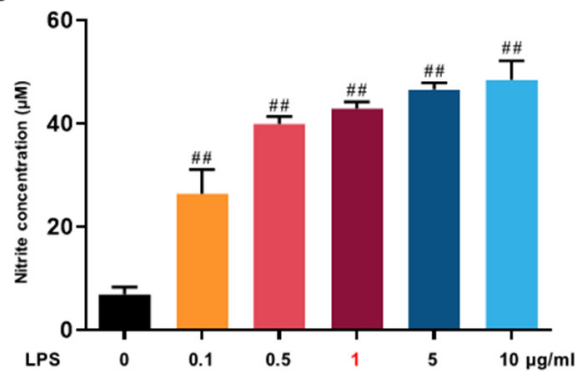

E

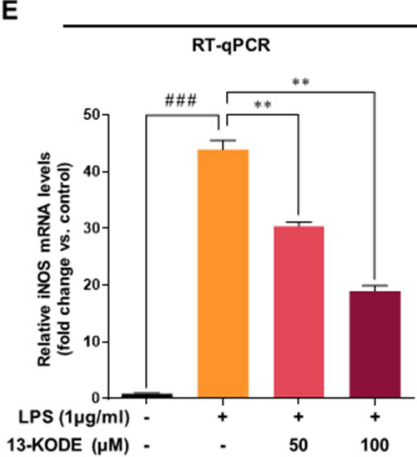

iNOS

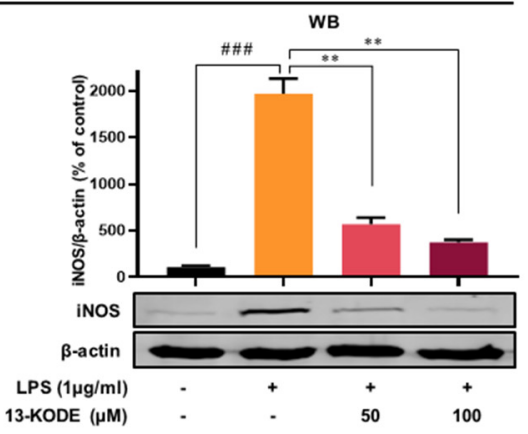

Figure 2. Effect of 13-KODE on cell proliferation and LPS-induced NO secretion and expression of the iNOS gene in RAW 264.7 macrophages. The cells were cultured with the indicated concentrations of 13-KODE and LPS. (A,B) Cell proliferation was determined with WST (4-[3-(4-Iodophenyl)-2-(4nitro-phenyl)-2H-5-tetrazolio]-1,3-benzene sulfonate). The results are shown as the percentage of surviving cells compared with control cells (without 13-KODE and LPS). (C) RAW 264.7 macrophage cells were treated with several concentrations of LPS for $24 \mathrm{~h}$, and NO production was determined using the NO assay. (D) RAW 264.7 cells ( $4 \times 10^{5}$ cells/well in six-well plates) were left untreated or were pretreated with $13-\operatorname{KODE}(25,50,75$, and $100 \mu \mathrm{M})$ prior to treatment with LPS $(1 \mu \mathrm{g} / \mathrm{mL})$ for 24 h. (E) Total RNA was purified from RAW 264.7 macrophage cells with or without the indicated concentrations of 13-KODE and treated with LPS $(1 \mu \mathrm{g} / \mathrm{mL})$ for $24 \mathrm{~h}$. The transcripts of iNOS were measured by quantitative reverse transcription polymerase chain reaction as described in Section 2. Protein lysates were isolated from the cells with or without 13-KODE and then stimulated with LPS $(1 \mu \mathrm{g} / \mathrm{mL})$ for $24 \mathrm{~h}$. The values correspond to the mean \pm standard deviation, $n=3$. ${ }^{\# \#} p<0.01$; \#\#\# $p<0.001 ;{ }^{* *} p<0.01$.

\subsection{3-KODE Inhibits LPS-Stimulated Proinflammatory Cytokines in RAW 264.7 Macrophage Cells}

The effect of 13-KODE on the elevated levels of TNF- $\alpha$ and IL- $1 \beta$ mRNA and protein in RAW 264.7 macrophage cells was determined by qPCR and ELISA. LPS induced mRNA and protein levels of IL-1 $\beta$ by 88 - and 7.4-fold, respectively, whereas 13-KODE $(100 \mu \mathrm{M})$ down-regulated expression by $52 \%$ and $72 \%$ compared with the LPS-treated control (Figure 3A). LPS induced transcripts and protein levels of TNF- $\alpha$ by 6.3- and 9.8-fold, respectively, whereas $13-\mathrm{KODE}(100 \mu \mathrm{M})$ treatment resulted in a $66 \%$ and $61 \%$ decrease compared with LPS-stimulated cells (Figure 3B). We found that 13-KODE decreased IL-1 $\beta$ and TNF- $\alpha$ secretion by inhibition of IL- $1 \beta$ and TNF- $\alpha$ gene expression (Figure 3A,B). LPS stimulation markedly induced the secretion of TNF- $\alpha$ and IL-1 $\beta$ in RAW 264.7 macrophages, whereas 13-KODE decreased LPS-induced production of TNF- $\alpha$ and IL-1 $\beta$ (Figure 3A,B). LPS induced the expression of TNF- $\alpha$ and IL-1 $\beta$ genes, whereas 13-KODE reduced LPSstimulated TNF- $\alpha$ and IL-1 $\beta$ gene expression (Figure $3 \mathrm{~A}, \mathrm{~B}$ ). These results indicate that 13-KODE decreases the inflammatory response of RAW 264.7 macrophage cells by reducing LPS-induced cytokine secretion. 


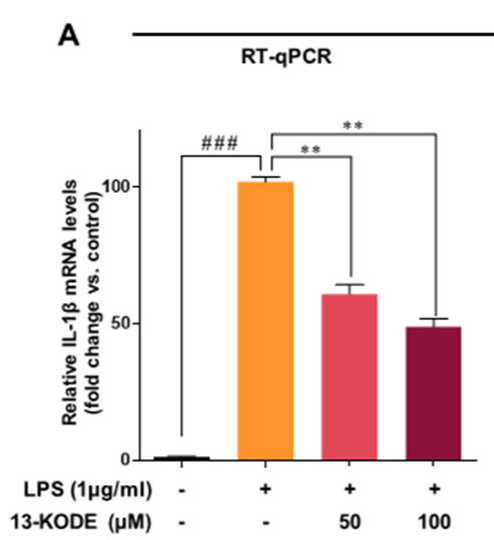

IL-1 $\beta$
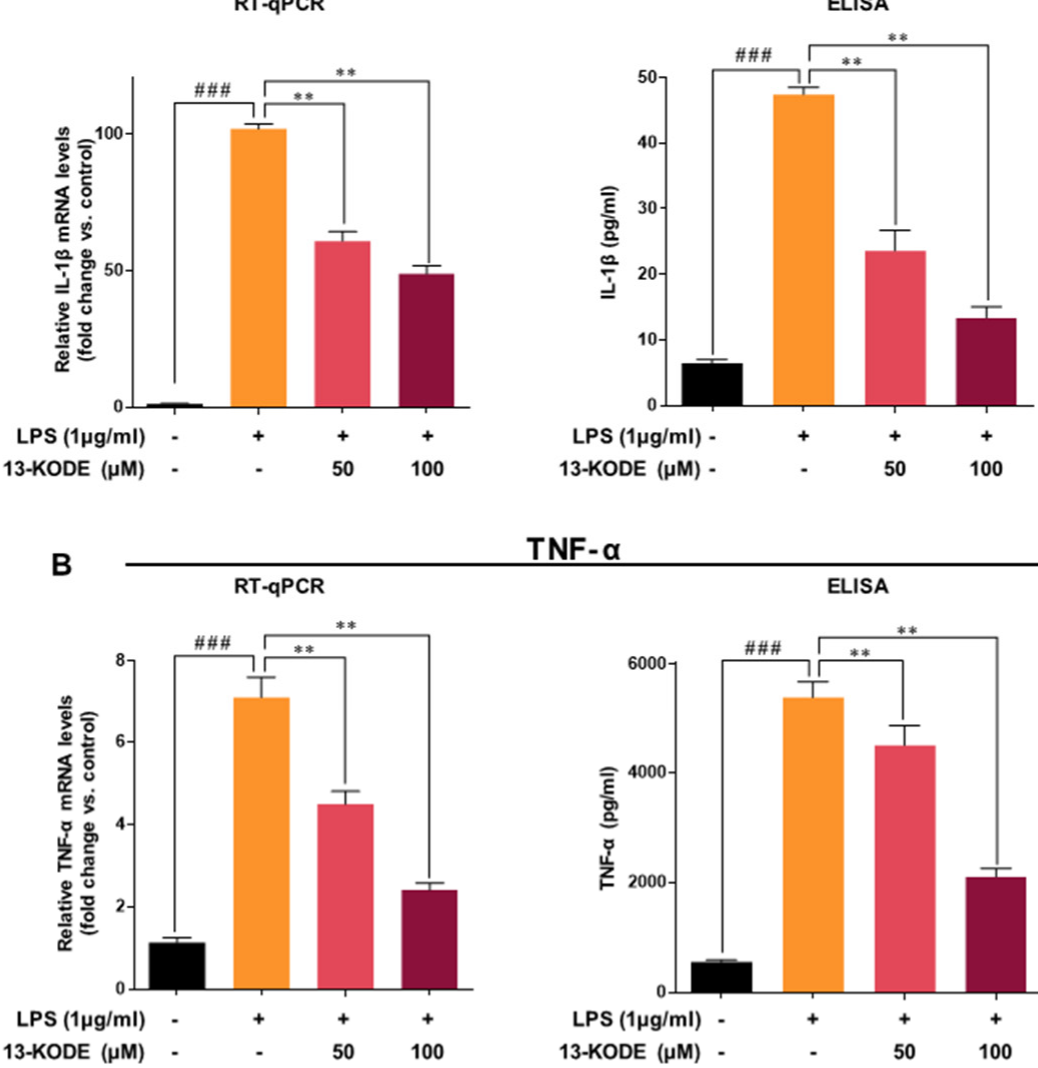

TNF- $\alpha$

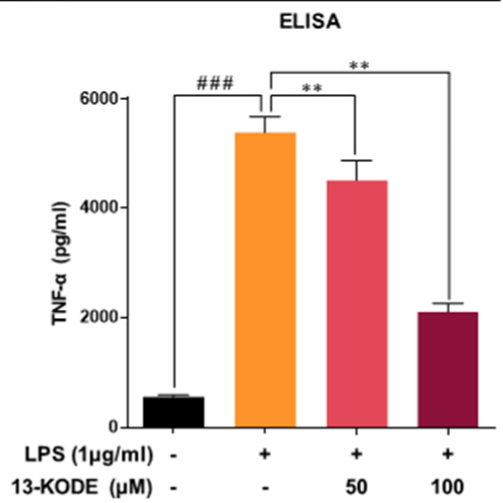

Figure 3. Inhibition of IL-1 $\beta$ and TNF- $\alpha$ production by 13-KODE in LPS-stimulated RAW 267.4 cells. RAW 264.7 cells were incubated with 13-KODE (50 and $100 \mu \mathrm{M})$ prior to stimulation with $1 \mu \mathrm{g} / \mathrm{mL}$ LPS for 1 day and total RNA was isolated. The transcript levels of IL-1 $\beta$ (A) and TNF- $\alpha$ (B) were measured by qRT-PCR. RAW 264.7 cells were incubated with 13-KODE (50 and $100 \mu \mathrm{M})$ prior to stimulation with $1 \mu \mathrm{g} / \mathrm{mL}$ LPS for 1 day and of IL-1 $\beta$ (A) and TNF- $\alpha$ (B) amounts in the cultured supernatants were measured using commercial ELISA kits. The values correspond to the mean \pm standard deviation, $n=3 .{ }^{* *} p<0.01 ;{ }^{\# \# \#} p<0.001$.

\subsection{The Effect of 13-KODE on NF- $\kappa B$ Signaling}

We determined the effects of 13-KODE on the NF- $\mathrm{KB}$ signaling pathway. The nuclear translocation of NF-kB p65 in LPS-treated cells was increased 1.6-fold compared with control cells, whereas 13-KODE reduced the levels of nuclear $\mathrm{p} 65$ by $67 \%$ compared with LPS-stimulated cells. The expression of cytosolic IKB was induced by 2.6-fold compared with the LPS-stimulated control. We found that LPS stimulation increased the nuclear level of NF-kB p65 protein and down-regulated the expression of IкB- $\alpha$. Moreover, 13-KODE treatment reduced the nuclear level of NF- $\mathrm{KB}$ (p65) and inhibited the downregulation of IкB- $\alpha$ expression in LPS-stimulated cells (Figure 4A). The immunofluorescence data revealed that LPS-treatment induced the nuclear translocation of NF- $\mathrm{BB}$ p65, whereas pretreatment with 13-KODE inhibited the nuclear translocation of NF- $\mathrm{KB}$ p65 in LPStreated cells (Figure 4B). We demonstrated that 13-KODE is a suppressor of LPS-stimulated NF- $\mathrm{kB}$ activation in RAW 264.7 macrophage cells. 


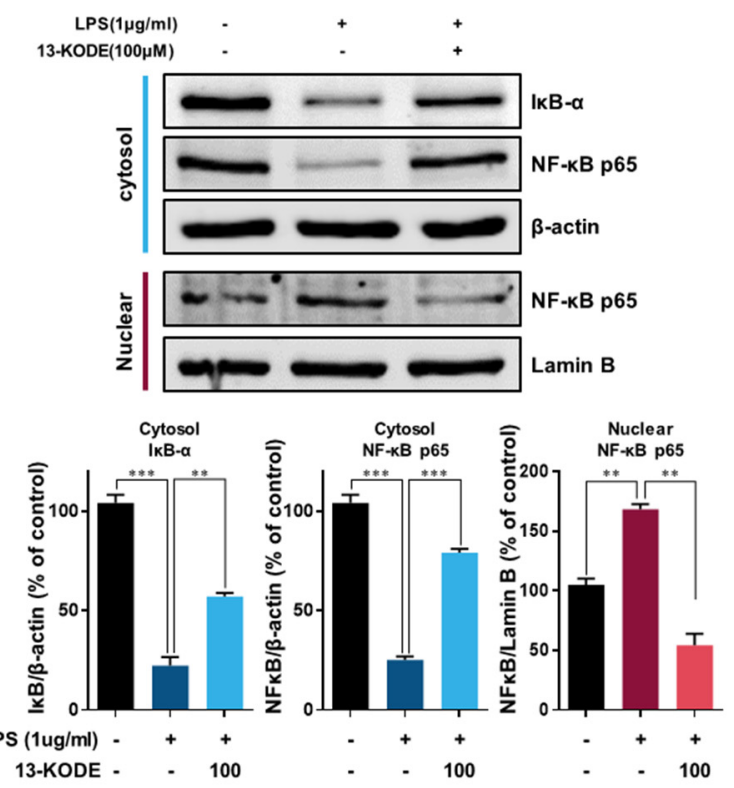

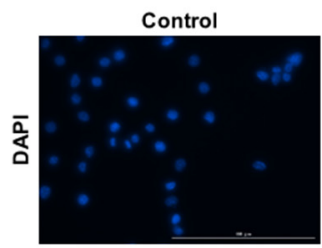

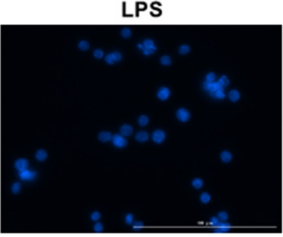

13-KODE + LPS
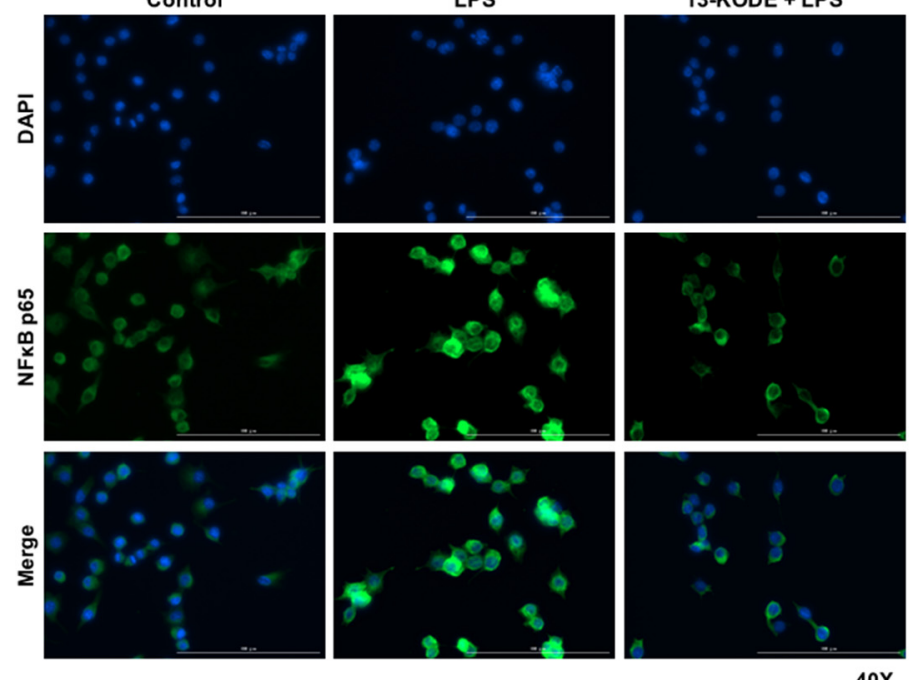

Figure 4. 13-KODE inhibits LPS-induced nuclear translocation of NF- $\mathrm{kB}$ in RAW264.7 cells. Macrophage cells were treated with $100 \mu \mathrm{M}$ 13-KODE for $1 \mathrm{~h}$ followed by treatment with LPS $(1 \mu \mathrm{g} / \mathrm{mL})$ for $30 \mathrm{~min}$. (A) Nuclear and cytosolic fractions were subjected to SDS-PAGE followed by Western blotting using the indicated primary antibodies. The amounts of lamin B and $\beta$-actin were used as internal controls for the nuclear and cytosolic fractions, respectively. The values correspond to the means \pm standard deviations, $n=3$. $^{* *} p<0.01^{* * *} p<0.001$. (B) RAW264.7 cells were pretreated with $100 \mu \mathrm{M}$ 13-KODE for $1 \mathrm{~h}$ and then treated with LPS $(1 \mu \mathrm{g} / \mathrm{mL})$ for $30 \mathrm{~min}$. The localization of NF-kB p65 and nuclei were determined by staining with anti-p65 (green) and DAPI (blue). Images were obtained by microscopy at 40X magnification and show representative macrophages (scale bar $=100 \mu \mathrm{m})$.

\subsection{3-KODE Inhibits LPS-Induced MAPK Activation in RAW 264.7 Macrophages}

Our data showed that LPS stimulation increased the levels of pERK1/2, p-p38, and pJNK by 4.8-, 5.5- and 7-fold, respectively, whereas 13-KODE resulted in a decrease of $66 \%$, $47 \%$, and $52 \%$, respectively, compared with LPS-stimulated control cells (Figure 5). We found that 13-KODE suppressed LPS-treated levels of pERK, p-p38, and pJNK (Figure 5) and inhibited the inflammatory response of LPS-induced RAW 264.7 cells by inhibiting MAPK signaling.

\subsection{3-KODE Reduced LPS-Induced ROS Accumulation in RAW 264.7 Cells}

Figure 6 shows that the LPS-induced cellular signal of CellROX Green was reversed by 13-KODE and NAC. Fluorescent signals were increased by 12.2-fold in LPS-treated cells and reduced by $88 \%$ in $13-\mathrm{KODE}-$ treated cells. This suggests that $13-\mathrm{KODE}$ is a strong candidate for ROS-reducing activity against LPS on murine RAW 264.7 macrophages. 

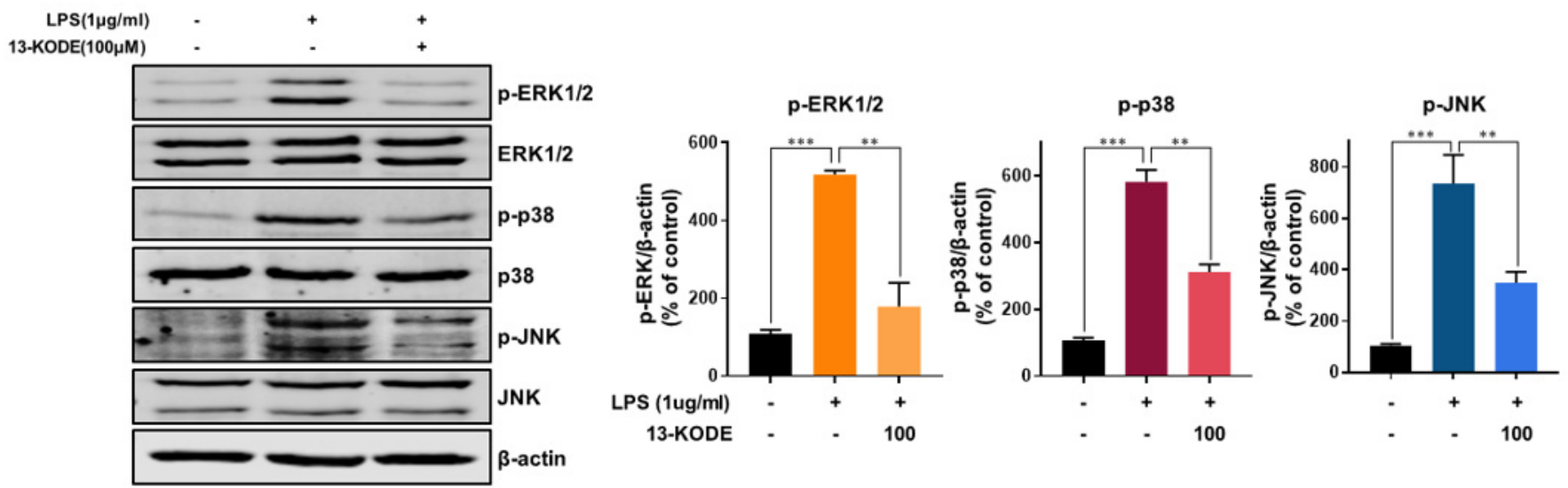

Figure 5. Inhibition of the LPS-induced activation of MAPKs by 13-KODE in RAW 264.7 macrophages. The cells were treated with $100 \mu \mathrm{M}$ of 13-KODE for $1 \mathrm{~h}$ prior to exposure to LPS $(1 \mu \mathrm{g} / \mathrm{mL})$ for $30 \mathrm{~min}$ and total protein was isolated. The protein extracts were subject to SDS-PAGE followed by Western blot analysis using the indicated primary antibodies. The amount of $\beta$-actin served as the internal control. pERK1/2, p-p38, and pJNK levels were determined. The values represent the mean \pm standard deviation, $n=3{ }^{* *} p<0.01 ;{ }^{* * *} p<0.001$.

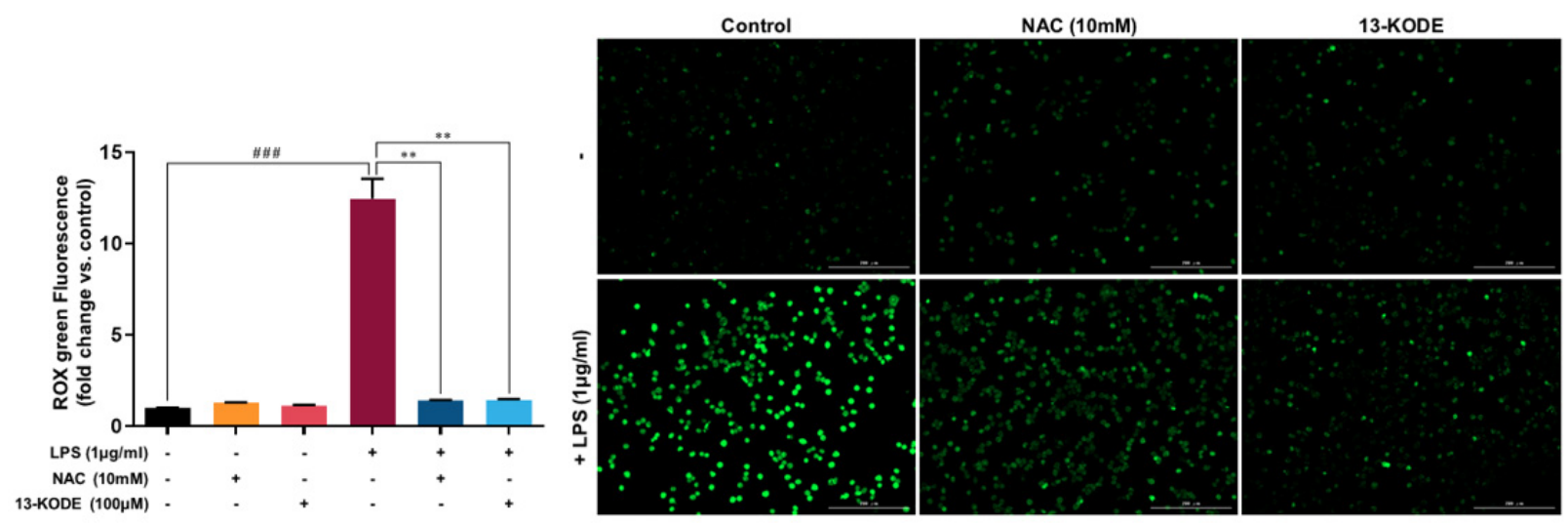

Figure 6. Effect of 13-KODE on LPS-induced ROS generation in RAW 264.7 macrophage cells. The ROS production of RAW 264.7 macrophages was monitored using CellROX Green dye assays. Macrophage cells were pretreated with $100 \mu \mathrm{M}$ of 13-KODE and NAC (10 mM) for $1 \mathrm{~h}$ prior to treatment with or without $1 \mu \mathrm{g} / \mathrm{mL}$ LPS for $30 \mathrm{~min}$. ROS data were visualized using a fluorescence microscope (magnification, $\times 100$ ) and representative photos are shown (scale bar; $100 \mu \mathrm{m})$. The values represent the mean \pm standard deviation, $n=3$. ${ }^{* *} p<0.01{ }^{\# \# \#} p<0.001$.

\subsection{Induction of HO-1 and Nfe2I2 Expression by 13-KODE in RAW 264.7 Cells}

The Nrf-2 (Nfe2I2) and HO-1 signaling axis represents a multiorgan protector that decreases oxidative stress in tissue and animal models $[17,28]$. We determined whether 13-KODE could induce the Nfe2I2/HO-1 signaling axis. 13-KODE increased HO-1 and Nfe2I2 protein levels by 20- and 4.6-fold, respectively, and reduced the expression of Keap1 protein at $12 \mathrm{~h}$ by $67 \%$. We found that $13-\mathrm{KODE}$ induced HO- 1 and Nfe2I2 protein levels (Figure 7A). We determined the cytosolic/nuclear location of Nfe2I2 during 13-KODE treatment and found that nuclear Nfe2I2 protein was increased by 5.3-fold. 13-KODE significantly increased the level of nuclear Nfe2I2 protein in nuclear fractions of RAW 264.7 macrophage lysates (Figure 7B). The results indicate that the antioxidant effect of 13-KODE is associated with the Nfe2I2/HO-1 signaling axis. 
A
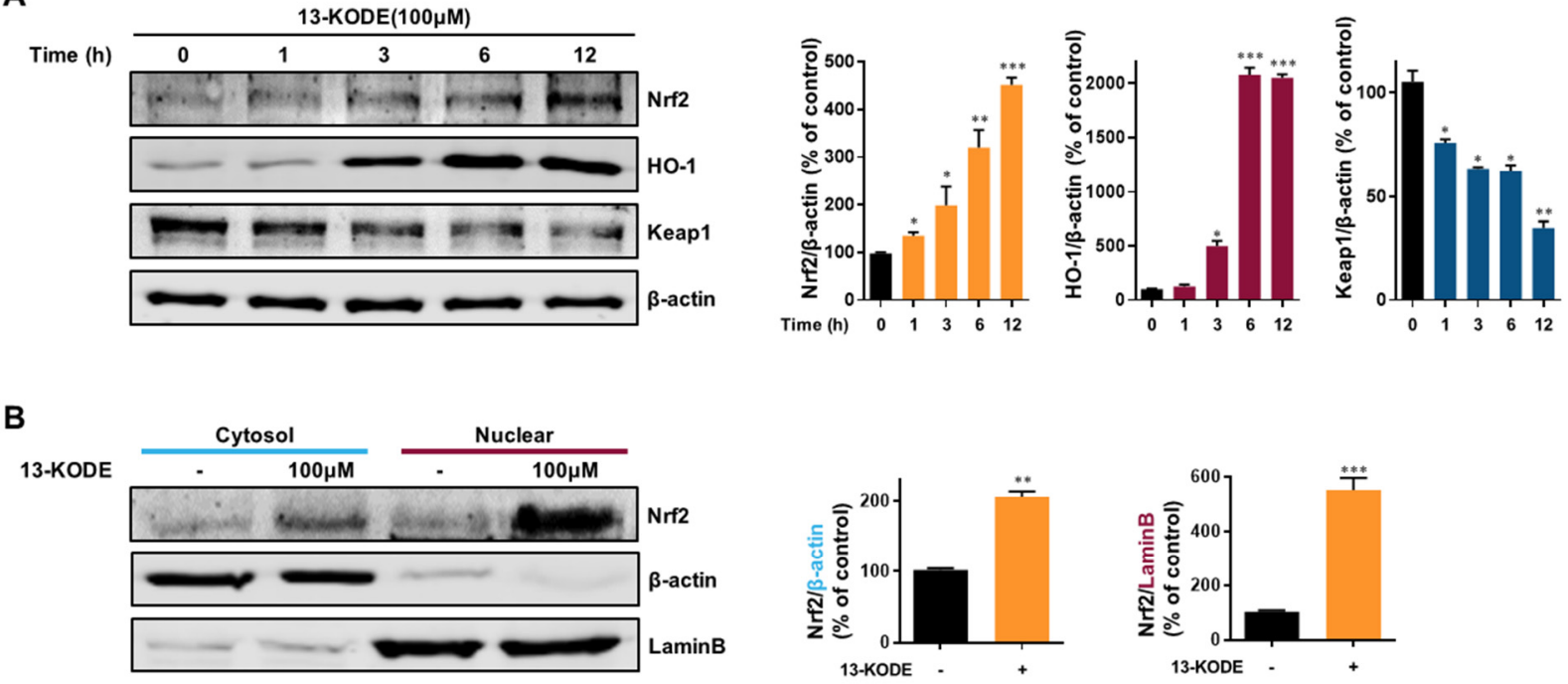

Figure 7. Induction of Nrf2 (Nfe2I2) and HO-1 proteins by 13-KODE in RAW 264.7 cells. (A) Macrophage cells were cultured with $100 \mu \mathrm{M}$ 13-KODE for the indicated times. Total protein was isolated by $10 \%$ SDS-PAGE and transferred to PVDF membranes. The membranes were probed with the indicated antibodies. $\beta$-Actin served as the internal control. (B) Macrophage cells were treated with $100 \mu \mathrm{M}$ 13-KODE for $12 \mathrm{~h}$. Nuclear and cytosolic proteins were probed with anti-Nfe2I2 (Nrf2) antibody. Proteins were visualized using the near-infrared (NIR) Western blot system. Lamin B and $\beta$-actin were used as internal controls for the nuclear and cytosolic proteins. The values represent the mean \pm standard deviation, $n=3 .{ }^{*} p<0.05 ;{ }^{* *} p<0.01 ;{ }^{* * *} p<0.001$.

\section{Discussion}

S. herbacea L. (glasswort) inhabits the western coastline of Korea; it is utilized as a food resource and consumed as a raw vegetable in salads and fermented food [36,37]. S. herbacea L. exhibits several biological effects including antioxidant, anti-inflammatory, and anticancer activity [37-40]. In the present study, we isolated an antioxidant from an S. herbacea L. extract using an antioxidant assay purification method, and the antioxidant was identified as 13-KODE, a 13-Oxo-9(Z), 11(E)-octadecadienoic acid. We demonstrated that 13-KODE extracted from glasswort exhibits anti-inflammatory activity on LPS-stimulated RAW 264.7 macrophages. 13-KODE (13-oxo-ode) is derived from 13-HODE by hydroxy fatty acid dehydrogenase [34]. LA is an essential fatty acid, and its derivatives consist of 9,10epoxy-12-octadecenoic acid (leukotoxin), 12,13-epoxy (EKODE), 9-hydroxyoctadacadienoic acid (9-HODE), 13-hydroxyoctadacadienoic acid (13-HODE), and 13-oxo-octadecadienoic acid (13-oxo-ode, 13-KODE). The derivatives of LA are synthesized by cyclooxygenases, lipoxygenases, and cytochrome p450 and are known to have pleiotropic effects [41].

The anti-inflammation properties of 13-KODE derived from S. herbacea L. have not been studied in murine macrophages. We examined the protective effect of 13-KODE on LPS-stimulated RAW 264.7 macrophages. LPS extracted from the cell wall of Gram negative bacteria may be used as a tool to determine the ability of specific compounds to inhibit inflammation [4]. After treatment with LPS, murine macrophages secrete inflammatory cytokines, such as TNF- $\alpha$, IL-6, and IL-1 $\beta$. In the present work, 13-KODE inhibited LPSstimulated NO production, TNF- $\alpha$ secretion, and IL-1 $\beta$ secretion. It suppressed LPSstimulated inflammation. The NF- $\mathrm{KB}$ pathway is essential for producing an inflammatory response and increases the expression of several proinflammatory genes [42]. This pathway is a target for the treatment of inflammatory diseases [43]. Our results indicated that 13-KODE inhibited the LPS-stimulated nuclear translocation of NF- $\mathrm{KB}$ (p65). We also found that 13-KODE suppressed LPS-stimulated MAPK activation (pERK1/2, pJNK, and $\mathrm{p}-\mathrm{p} 38$ ) and LPS-stimulated inflammation by modulating MAPK signaling and NF- $\mathrm{kB}$ (p65) nuclear translocation. 
In murine macrophage cells, LPS-induced cellular ROS accumulation increased the inflammatory mediators, and cytokine secretion [44]. The crosstalk between inflammation and oxidative stress is important in diseases. LPS-induced oxidative stress and inflammation in bovine mammary epithelial cells and acute lung injury were inhibited by hydroxytyrosol and adamantly retinoid ST1926 [19-21]. Our data showed that LPS-induced oxidative stress and inflammation in RAW 264.7 macrophage cells were inhibited by 13KODE. It is considered that hydroxytyrosol, retinoid ST1926, and 13-KODE compounds can regulate the crosstalk between inflammation and oxidative stress. ROS acts as a mediator of receptor-mediated signaling. Lipoxygenases (LOXs) and nicotinamide adenine dinucleotide phosphate oxidases of immune cells induce the production of ROS during receptor-mediated signaling. LPS-treatment increases ROS production and NF- $\mathrm{B}$ activation [44]. We demonstrated that 13-KODE reduced LPS-stimulated ROS production in murine macrophages and inhibited ROS accumulation, which represents an important anti-inflammatory effect of 13-KODE.

The Nfe2I2/HO-1 axis is a multiorgan protective mechanism that protects cells against oxidative stress. It inhibits the transcriptional activation of proinflammatory cytokines and inflammatory genes [45] as well as oxidative stress in cells and organs [46]. The Nfe2I2/sMaf transcription factor complex binds to the antioxidant response element and activates the transcription of the HO-1 gene. The bilirubin produced by HO- 1 exhibits antioxidant and cytoprotective effects. We showed that 13-KODE increased Nfe2I2 and HO1 protein levels and $\mathrm{Nfe} 2 \mathrm{I} 2 / \mathrm{HO}-1$ axis signaling. It also increased the anti-inflammatory response of LPS-induced macrophage cells. Furthermore, we also found that 13-KODE increased Nfe2I2 and HO-1 protein levels and decreased Keap1.

13-KODE, a derivative of LA, has been isolated from various tomato plants. It exhibits antioxidant effects and acts as a PPAR $\alpha$ agonist [33,34]. 13-HODE, a precursor of 13-KODE act as a mitogenic signal responsible for LA-dependent growth in hepatoma 7288CTC cells in vivo [47]. 13-KODE shows structural stability under hot and acidic conditions. Our results showed that 13-KODE exhibits anti-inflammatory effects on murine RAW 264.7 cells not only by blocking ROS accumulation, MAPK activities and activating NF- $\mathrm{B}$ signaling, but also by increasing Nrf-2/HO-1 signaling (Figure 8). Our study showed that $13-\mathrm{KODE}$ results in an anti-inflammatory effect and may have the potential for treating inflammatory diseases.

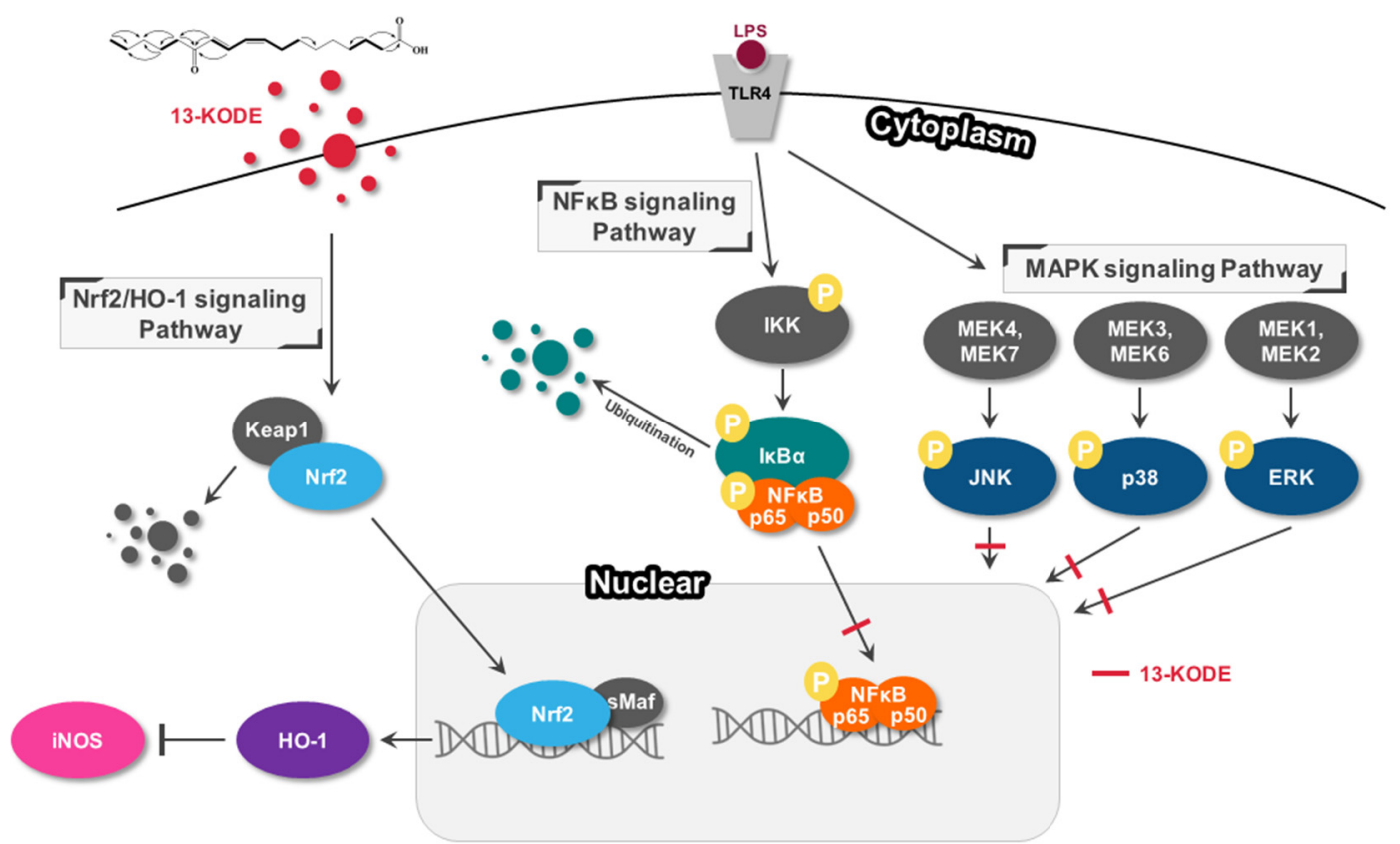

Figure 8. Scheme showing the mechanisms of the anti-inflammatory and cytoprotective effects of 13-KODE on LPS-induced inflammation. 


\section{Conclusions}

We purified an antioxidant compound from S. herbacea L. (glasswort) and found that it exhibits significant antioxidant activity. Purification of the antioxidant compound was carried out through antioxidant assay-based isolation and large sample preparation. Using NMR spectrometry, we identified the purified compound to be 13-KODE. We determined that it has a protective effect on LPS-stimulated inflammation of macrophages. 13-KODE exhibits its anti-inflammatory activity in LPS-stimulated macrophages by inhibiting proinflammatory cytokine production, LPS-stimulated ROS accumulation, LPS-induced MAPK activation and activating Nfe2I2/HO-1 signaling axis. We showed that 13-KODE produces anti-inflammatory effects and has the potential for use in treating inflammatory diseases.

Supplementary Materials: The following data are available online at online https://www.mdpi. com/article/10.3390/antiox11020180/s1. Table S1. Specific Real-time RT-qPCR primer sequences containing iNOS, IL-1 $\beta$, TNF- $\alpha$, and $\beta$-actin genes. Figure S1: Purification of an antioxidant from S. herbacea $\mathrm{L}$. extracts using $\mathrm{SiO}_{2}$ gel chromatography eluted with $\mathrm{CHCl}_{3}: \mathrm{MeOH}(30: 1)$. Active fraction: \#6. Figure S2. Purification of an antioxidant from S. herbacea L. extracts using Sephadex LH-20 gel chromatography eluted with $\mathrm{MeOH}$. Active fraction: \#2. Figure S3. Purification of an antioxidant from the $S$. herbacea L. extracts using preparative thin layer chromatography with $\mathrm{CHCl} 3: \mathrm{MeOH}$ (20:1). Active fraction: \#1. Figure S4. Purification procedure of an antioxidant from the S. herbacea L. extracts using preparatory HPLC with acetonitrile. Figure S5. ESI-mass spectrometry of the purified sample. Figure S6. ${ }^{1} \mathrm{H}$ NMR and ${ }^{13} \mathrm{C}$ NMR spectra of the purified sample. Figure S7. HMQC spectrum of the purified sample. Figure S8. ${ }^{1} \mathrm{H}-{ }^{1} \mathrm{H}$ COSY spectrum of the purified sample. Figure S9. HMBC spectrum of the purified sample. Figure S10. HMBC correlations and ${ }^{1} \mathrm{H}$ (red), ${ }^{1} \mathrm{C}$ (blue) peak assignments of the purified sample.

Author Contributions: H.S.C. and Y.-C.K. carried out all of the experiments and wrote the manuscript. S.-L.K. and B.-S.Y. helped with the experiments. D.-S.L. supervised and reviewed the manuscript. All authors have checked and agreed to the published version of the manuscript.

Funding: This research was supported by the Basic Science Research Program through the National Research Foundation of Korea (NRF) funded by the Ministry of Education (NRF-2016R1A6A1A03012862, NRF-2018R1D1A1B07045261, and NRF-2020R1A2C1006316). This research was supported by the 2020 Scientific Promotion Program funded by Jeju National University. We thank the Korea Basic Science Institute (National Research Facilities and Equipment Center) grant funded by the Ministry of Education, Korea (Grant N0.: 2020R1A6C101A188).

Institutional Review Board Statement: Not applicable.

Informed Consent Statement: Not applicable.

Data Availability Statement: Data is contained within the article and Supplementary Materials.

Acknowledgments: This research was supported by the National University Development Project funded by the Ministry of Education (Korea) and the National Research Foundation of Korea (2021).

Conflicts of Interest: The authors declare no conflict of interest.

\section{References}

1. Ferrero-Miliani, L.; Nielsen, O.H.; Andersen, P.S.; Girardin, S.E. Chronic Inflammation: Importance of NOD2 and NALP3 in Interleukin-1beta Generation. Clin. Exp. Immunol. 2007, 147, 227-235. [CrossRef]

2. Rock, K.L.; Kono, H. The Inflammatory Response to Cell Death. Annu. Rev. Pathol. 2008, 3, 99-126. [CrossRef] [PubMed]

3. Chen, L.; Deng, H.; Cui, H.; Fang, J.; Zuo, Z.; Deng, J.; Li, Y.; Wang, X.; Zhao, L. Inflammatory Responses and InflammationAssociated Diseases in Organs. Oncotarget 2018, 9, 7204-7218. [CrossRef] [PubMed]

4. Cuschieri, J.; Maier, R.V. Oxidative Stress, Lipid Rafts, and Macrophage Reprogramming. Antioxid. Redox Signal. 2007, 9, 1485-1497. [CrossRef]

5. $\quad$ Lucas, K.; Maes, M. Role of the Toll Like Receptor (TLR) Radical Cycle in Chronic Inflammation: Possible Treatments Targeting the TLR4 Pathway. Mol. Neurobiol. 2013, 48, 190-204. [CrossRef]

6. Leiro, J.; Alvarez, E.; Arranz, J.A.; Laguna, R.; Uriarte, E.; Orallo, F. Effects of Cis-Resveratrol on Inflammatory Murine Macrophages: Antioxidant Activity and Down-Regulation of Inflammatory Genes. J. Leukoc. Biol. 2004, 75, 1156-1165. [CrossRef] [PubMed] 
7. Su, Y.W.; Chiou, W.F.; Chao, S.H.; Lee, M.H.; Chen, C.C.; Tsai, Y.C. Ligustilide Prevents LPS-induced iNOS Expression in RAW 264.7 Macrophages by Preventing ROS Production and Down-Regulating the MAPK, NF-kappaB and AP-1 Signaling Pathways. Int. Immunopharmacol. 2011, 11, 1166-1172. [CrossRef] [PubMed]

8. Murakami, A.; Ohigashi, H. Targeting NOX, INOS and COX-2 in Inflammatory Cells: Chemoprevention Using Food Phytochemicals. Int. J. Cancer 2007, 121, 2357-2363. [CrossRef] [PubMed]

9. Muller, A.K.; Albrecht, F.; Rohrer, C.; Koeberle, A.; Werz, O.; Schlormann, W.; Glei, M.; Lorkowski, S.; Wallert, M. Olive Oil Extracts and Oleic Acid Attenuate the LPS-Induced Inflammatory Response in Murine RAW264.7 Macrophages but Induce the Release of Prostaglandin E2. Nutrients 2021, 13, 4437. [CrossRef] [PubMed]

10. Klapproth, J.M.; Sasaki, M. Bacterial Induction of Proinflammatory Cytokines in Inflammatory Bowel Disease. Inflamm. Bowel Dis. 2010, 16, 2173-2179. [CrossRef] [PubMed]

11. Liu, K.; Shi, R.; Wang, S.; Liu, Q.; Zhang, H.; Chen, X. Intermedin Inhibits the Ox-LDL-Induced Inflammation in RAW264.7 Cells by Affecting Fatty Acid-Binding Protein 4 through the PKA Pathway. Front. Pharmacol. 2021, 12, 724777. [CrossRef] [PubMed]

12. Guha, M.; Mackman, N. LPS Induction of Gene Expression in Human Monocytes. Cell Signal. 2001, 13, 85-94. [CrossRef]

13. Huang, B.P.; Lin, C.H.; Chen, H.M.; Lin, J.T.; Cheng, Y.F.; Kao, S.H. AMPK Activation Inhibits Expression of Proinflammatory Mediators through Downregulation of PI3K/p38 MAPK and NF-kappaB Signaling in Murine Macrophages. DNA Cell Biol. 2015, 34, 133-141. [CrossRef] [PubMed]

14. Wu, Z.; Liao, F.; Luo, G.; Qian, Y.; He, X.; Xu, W.; Ding, S.; Pu, J. NR1D1 Deletion Induces Rupture-Prone Vulnerable Plaques by Regulating Macrophage Pyroptosis via the NF-kappaB/NLRP3 Inflammasome Pathway. Oxid. Med. Cell. Longev. 2021, 5217572.

15. Huang, P.; Hong, J.; Mi, J.; Sun, B.; Zhang, J.; Li, C.; Yang, W. Polyphenols Extracted from Enteromorpha Clathrata Alleviates Inflammation in Lipopolysaccharide-Induced RAW 264.7 Cells by Inhibiting the MAPKs/NF-kappaB Signaling Pathways. J. Ethnopharmacol. 2021, 286, 114897. [CrossRef]

16. Pearson, G.; Robinson, F.; Beers Gibson, T.; Xu, B.E.; Karandikar, M.; Berman, K.; Cobb, M.H. Mitogen-Activated Protein (MAP) Kinase Pathways: Regulation and Physiological Functions. Endocr. Rev. 2001, 22, 153-183.

17. Huang, Y.; Li, W.; Su, Z.Y.; Kong, A.N. The Complexity of the Nrf2 Pathway: Beyond the Antioxidant Response. J. Nutr. Biochem. 2015, 26, 1401-1413. [CrossRef]

18. Nakajima, S.; Kitamura, M. Bidirectional Regulation of NF-kappaB by Reactive Oxygen Species: A Role of Unfolded Protein Response. Free Radic. Biol. Med. 2013, 65, 162-174. [CrossRef]

19. Fusco, R.; Cordaro, M.; Siracusa, R.; Peritore, A.F.; D’Amico, R.; Licata, P.; Crupi, R.; Gugliandolo, E. Effects of Hydroxytyrosol against Lipopolysaccharide-Induced Inflammation and Oxidative Stress in Bovine Mammary Epithelial Cells: A Natural Therapeutic Tool for Bovine Mastitis. Antioxidants. 2020, 9, 693. [CrossRef] [PubMed]

20. Crupi, R.; Palma, E.; Siracusa, R.; Fusco, R.; Gugliandolo, E.; Cordaro, M.; Impellizzeri, D.; De Caro, C.; Calzetta, L.; Cuzzocrea, S.; et al. Protective Effect of Hydroxytyrosol against Oxidative Stress Induced by the Ochratoxin in Kidney Cells: In vitro and in vivo Study. Front. Vet. Sci. 2020, 7, 161. [CrossRef] [PubMed]

21. Dong, Z.; Yuan, Y. Accelerated Inflammation and Oxidative Stress Induced by LPS in Acute Lung Injury: Iotanhibition by ST1926. Int. J. Mol. Med. 2018, 41, 3405-3421. [CrossRef] [PubMed]

22. Meital, L.T.; Windsor, M.T.; Perissiou, M.; Schulze, K.; Magee, R.; Kuballa, A.; Golledge, J.; Bailey, T.G.; Askew, C.D.; Russell, F.D Omega-3 Fatty Acids Decrease Oxidative Stress and Inflammation in Macrophages from Patients with Small Abdominal Aortic Aneurysm. Sci. Rep. 2019, 9, 12978. [CrossRef] [PubMed]

23. Siracusa, R.; Fusco, R.; Peritore, A.F.; Cordaro, M.; D'Amico, R.; Genovese, T.; Gugliandolo, E.; Crupi, R.; Smeriglio, A.; Mandalari, G.; et al. The Antioxidant and Anti-Inflammatory Properties of Anacardium occidentale L. Cashew Nuts in a Mouse Model of Colitis. Nutrients 2020, 12, 834. [CrossRef] [PubMed]

24. Zhang, H.; Xu, X.; Liu, Z.; Sun-Waterhouse, D.; Wang, J.; Ma, C.; Waterhouse, G.I.N.; Kang, W. Effects of Edpetiline from Fritillaria on Inflammation and Oxidative Stress induced by LPS Stimulation in RAW264.7 Macrophages. Acta Biochim. Biophys. Sin. 2021, 53, 229-237. [CrossRef] [PubMed]

25. Kang, H.; Lee, Y.; Bae, M.; Park, Y.K.; Lee, J.Y. Astaxanthin Inhibits Alcohol-Induced Inflammation and Oxidative Stress in Macrophages in a Sirtuin 1-Dependent Manner. J. Nutr. Biochem. 2020, 85, 108477. [CrossRef] [PubMed]

26. Deshane, J.; Wright, M.; Agarwal, A. Heme Oxygenase-1 Expression in Disease States. Acta Biochim. Pol. 2005, 52, 273-284. [CrossRef] [PubMed]

27. Loboda, A.; Damulewicz, M.; Pyza, E.; Jozkowicz, A.; Dulak, J. Role of Nrf2/HO-1 System in Development, Oxidative Stress Response and Diseases: An Evolutionarily Conserved Mechanism. Cell Mol. Life Sci. 2016, 73, 3221-3247. [CrossRef] [PubMed]

28. Kang, K.A.; Hyun, J.W. Oxidative Stress, Nrf2, and Epigenetic Modification Contribute to Anticancer Drug Resistance. Toxicol. Res. 2017, 33, 1-5. [CrossRef] [PubMed]

29. Kim, M.S.; Seo, J.Y.; Oh, J.; Jang, Y.K.; Lee, C.H.; Kim, J.S. Neuroprotective Effect of Halophyte Salicornia herbacea L. Is Mediated by Activation of Heme Oxygenase-1 in Mouse Hippocampal HT22 Cells. J. Med. Food 2017, 20, 140-151. [CrossRef] [PubMed]

30. Park, S.H.; Ko, S.K.; Choi, J.G.; Chung, S.H. Salicornia Herbacea Prevents High Fat Diet-Induced Hyperglycemia and Hyperlipidemia in ICR Mice. Arch. Pharm. Res. 2006, 29, 256-264. [CrossRef] [PubMed]

31. Sung, J.H.; Park, S.H.; Seo, D.H.; Lee, J.H.; Hong, S.W.; Hong, S.S. Antioxidative and Skin-Whitening Effect of an Aqueous Extract of Salicornia Herbacea. Biosci. Biotechnol. Biochem. 2009, 73, 552-556. [CrossRef] 
32. Shen, T.; Heo, S.I.; Wang, M.H. Involvement of the p38 MAPK and ERK Signaling Pathway in the Anti-Melanogenic Effect of Methyl 3,5-dicaffeoyl Quinate in B16F10 Mouse Melanoma Cells. Chem. Biol. Interact. 2012, 199, 106-111. [CrossRef]

33. Takahashi, H.; Kim, Y.I.; Hirai, S.; Goto, T.; Ohyane, C.; Tsugane, T.; Konishi, C.; Fujii, T.; Inai, S.; Ijijima, Y.; et al. Comparative and Stability Analyses of 9- and 13-Oxo-octadecadienoic Acids in Various Species of Tomato. Biosci. Biotechnol. Biochem. 2011, 75, 1621-1624. [CrossRef]

34. Vangaveti, V.N.; Jansen, H.; Kennedy, R.L.; Malabu, U.H. Hydroxyoctadecadienoic Acids: Oxidised Derivatives of Linoleic Acid and Their Role in Inflammation Associated with Metabolic Syndrome and Cancer. Eur. J. Pharm. 2016, 785, 70-76. [CrossRef] [PubMed]

35. Brand-Williams, W.; Cuvelier, M.E.; Berset, C. Use of a Free-Radical Method to Evaluate Antioxidant Activity. Food Sci. Technol. -Lebensm. -Wiss. Technol. 1995, 28, 25-30. [CrossRef]

36. Cho, J.Y.; Kim, J.Y.; Lee, Y.G.; Lee, H.J.; Shim, H.J.; Lee, J.H.; Kim, S.J.; Ham, K.S.; Moon, J.H. Four New Dicaffeoylquinic Acid Derivatives from Glasswort (Salicornia herbacea L.) and Their Antioxidative Activity. Molecules 2016, 21, 1097. [CrossRef]

37. Ha, B.J.; Lee, S.H.; Kim, H.J.; Lee, J.Y. The Role of Salicornia Herbacea in Ovariectomy-Induced Oxidative Stress. Biol. Pharm. Bull. 2006, 29, 1305-1309. [CrossRef]

38. Im, S.A.; Kim, K.; Lee, C.K. Immunomodulatory Activity of Polysaccharides Isolated from Salicornia Herbacea. Int. Immunopharmacol. 2006, 6, 1451-1458. [CrossRef]

39. Ko, Y.C.; Choi, H.S.; Kim, J.H.; Kim, S.L.; Yun, B.S.; Lee, D.S. Coriolic Acid (13-(S)-Hydroxy-9Z, 11E-octadecadienoic Acid) from Glasswort (Salicornia herbacea L.) Suppresses Breast Cancer Stem Cell through the Regulation of c-Myc. Molecules 2020, $25,4950$. [CrossRef]

40. Ryu, D.S.; Kim, S.H.; Lee, D.S. Anti-Proliferative Effect of Polysaccharides from Salicornia Herbacea on Induction of G2/M arrest and Apoptosis in Human Colon Cancer Cells. J. Microbiol. Biotechnol. 2009, 19, 1482-1489. [CrossRef] [PubMed]

41. Reinaud, O.; Delaforge, M.; Boucher, J.L.; Rocchiccioli, F.; Mansuy, D. Oxidative Metabolism of Linoleic Acid by Human Leukocytes. Biochem. Biophys. Res. Commun. 1989, 161, 883-891. [CrossRef]

42. Oeckinghaus, A.; Ghosh, S. The NF-kappaB Family of Transcription Factors and Its Regulation. Cold Spring Harb. Perspect. Biol. 2009, 1, a000034. [CrossRef] [PubMed]

43. Liang, N.; Sang, Y.; Liu, W.; Yu, W.; Wang, X. Anti-Inflammatory Effects of Gingerol on Lipopolysaccharide-Stimulated RAW 264.7 Cells by Inhibiting NF-kappaB Signaling Pathway. Inflammation 2018, 41, 835-845. [CrossRef] [PubMed]

44. Kim, S.Y.; Kim, T.B.; Moon, K.A.; Kim, T.J.; Shin, D.; Cho, Y.S.; Moon, H.B.; Lee, K.Y. Regulation of Pro-Inflammatory Responses by Lipoxygenases via Intracellular Reactive Oxygen Species in vitro and in vivo. Exp. Mol. Med. 2008, 40, 461-476. [CrossRef] [PubMed]

45. Zhu, H.; Jia, Z.; Li, Y.R. Nrf2 Signaling in Macrophages. React. Oxyg. Species (Apex) 2016, 2, 417-420. [CrossRef] [PubMed]

46. Habtemariam, S. The Nrf2/HO-1 Axis as Targets for Flavanones: Neuroprotection by Pinocembrin, Naringenin, and Eriodictyol. Oxid. Med. Cell. Longev. 2019, 2019, 4724920. [CrossRef] [PubMed]

47. Sauer, L.A.; Dauchy, R.T.; Blask, D.E.; Armstrong, B.J.; Scalici, S. 13-Hydroxyoctadecadienoic Acid Is the Mitogenic Signal for Linoleic Acid-Dependent Growth in Rat Hepatoma 7288CTC in vivo. Cancer Res. 1999, 59, 4688-4692. 